\title{
Sinusoidal portal hypertension in hepatic amyloidosis
}

Service d'Hépatogastroentérologie and Laboratoire d'Anatomie et de Cytologie

Pathologiques, Hôpital de la Source, Orléans,

France

E Bion

E A Pariente

F Maitre

Service d'Hépatologie and Unité de Recherches de Physiopathologie

Hépatique (INSERM

U-24) and Laboratoire

d'Anatomie et de

Cytologie Pathologiques,

Hôpital Beaujon, Clichy,

France

$R$ Brenard

D Lebrec

C Degott

J P Benhamou

Correspondence to:

DrE A Pariente, CHR de Pau, BP 1156, F 64011 Pau, France.

Accepted for publication 26 March 1990

\author{
E Bion, R Brenard, E A Pariente, D Lebrec, C Degott, F Maitre, J P Benhamou
}

detected in the serum or urine. Endoscopy showed no oesophageal varices. Ultrasound showed a homogeneous enlarged liver with ascites and patent portal and hepatic veins. Hepatic venous catheterisation and transvenous liver biopsy were performed. Wedged and free hepatic venous pressures were found to be 19 and $7 \mathrm{mmHg}$ respectively, with a pressure gradient of $12 \mathrm{mmHg}$ (normal values, $1-4 \mathrm{mmHg}$ ). Right atrial pressure was $7 \mathrm{mmHg}$. Histological examination of the liver biopsy specimen showed massive amyloid deposits in the Disse's space with considerable compression atrophy of hepatic sinusoids and hepatocytes. A rectal biopsy specimen showed large subepithelial and vascular deposits of amyloid. Bone marrow biopsy tissue showed infiltration with lymphoplasmocytoid cells bearing IgM with kappa light chains and prominent interstitial deposits of amyloid. Primary AL type amyloidosis with severe liver, kidney, and bone marrow infiltration was diagnosed. Gastrointestinal bleeding from an unknown origin occurred. The patient died from sepsis and renal failure 15 days after admission to hospital.

megaly and moderate abnormalities of function tests are the most frequent findings. ${ }^{1-4}$ Portal hypertension is an uncommon complication of this disorder and its mechanism remains unclear. In this study, we report the results of hepatic vein pressure measurements in five patients with hepatic amyloidosis, two of whom had portal hypertension. In addition, we evaluated the value of the hepatic venous pressure gradient to the degree of amyloidosis infiltration into the liver.

\section{Case reports}

PATIENT 1

A 62 year old woman was admitted to hospital on 15 May 1987 because of jaundice, weight loss, and fatigue of eight months' duration. Clinical examination showed jaundice, a firm hepatomegaly measuring $16 \mathrm{~cm}$ on the right midclavicular line, two spider angiomas, and moderate ascites. There was no splenomegaly. Results of liver tests are given in Table $I$. Proteinuria was $3 \mathrm{~g} /$ day. No $M$ component was

TABLE I Biochemical features in five patients with hepatic amyloidosis

\begin{tabular}{lllll}
\hline Patient & $\begin{array}{l}\text { Serum } \\
\text { bilirubin } \\
(\mu \text { mol/l) })\end{array}$ & $\begin{array}{l}\text { Alkaline } \\
\text { phosphatases } \\
\left(\text { IU } / l^{\star}\right)\end{array}$ & $\begin{array}{l}\text { Prothrombin } \\
\text { time } \\
(\% \text { of normal })\end{array}$ & $\begin{array}{l}\text { Serum } \\
\text { albumin } \\
(\mathrm{g} / \mathrm{l})\end{array}$ \\
\hline 1 & 175 & 512 & 39 & 18 \\
2 & 25 & 625 & 70 & 32 \\
3 & 11 & 312 & 90 & 40 \\
4 & 6 & 250 & 89 & 31 \\
5 & 10 & 150 & 65 & 22 \\
\hline
\end{tabular}

$\star$ Normal: <125 IU/1.

\section{PATIENT 2}

A 66 year old man was admitted to hospital on 1 July 1987 for dyspnoea of two months' duration and hepatomegaly. Clinical examination showed a firm hepatomegaly measuring $19 \mathrm{~cm}$ on the right mid-clavicular line, tense ascites, ankle oedema, distended jugular veins, and tachycardia. Results of liver tests are given in Table I. An $M$ component (IgA lambda) was present in the serum and lambda light chains in urine. Proteinuria was $0.6 \mathrm{~g} /$ day. No oesophageal varices were seen at endoscopy. Abdominal ultrasound showed a homogeneous enlarged liver with patent portal and slight dilated hepatic veins. Cardiac ultrasound showed hypertrophy of the interventricular septum and the posterior wall without ventricular dilatation and a moderate pericardial effusion. There was no detectable skeletal lesion on $x$ ray examinations. A hepatic venous catheterisation and a transvenous liver biopsy were performed. Wedged and free hepatic venous pressures were 20 and $4 \mathrm{mmHg}$ respectively, with a pressure gradient of $16 \mathrm{mmHg}$. Right atrial pressure was $4 \mathrm{mmHg}$. Histological examination of the liver biopsy specimen showed diffuse and massive perisinusoidal amyloid deposits (Fig 1). Submucosal deposits of amyloid were found in the gastric and duodenal biopsy specimens. Bone marrow biopsy tissue showed infiltration with mature plasmocytes bearing IgA with lambda light chains and interstitial deposits of amyloid. Primary AL type amyloidosis with severe liver 
and cardiac involvement, possibly associated with myeloma, was diagnosed. The patient was treated with melphalan and prednisone without improvement and died from arrythmia five months after hospital admission.

\section{PATIENT 3}

A 50 year old man was admitted to hospital on 5 January 1987 because of abnormal liver tests over three months. Six months earlier he had developed nephrotic syndrome and renal failure due to renal amyloidosis associated with multiple myeloma. At this time chronic haemodialysis was started and he was treated with cyclophosphamide, vincristine, and prednisone every two or three months. At hospital admission, clinical examination showed neither hepatomegaly nor ascites. Results of liver tests are given in Table I. An $M$ component (IgG lambda) was present in the serum. Hepatic venous catheterisation showed wedged and free hepatic venous pressures of 8 and $6 \mathrm{mmHg}$ respectively, and a pressure gradient of $2 \mathrm{mmHg}$. Right atrial pressure was $5 \mathrm{mmHg}$. Histological examination of the transvenous liver biopsy specimen showed discrete and sparse perisinusoidal amyloid deposits. In January 1989, the $M$ component (IgG lambda) was found to be decreased in the serum. Chronic haemodialysis and chemotherapy were continued.

\section{PATIENT 4}

A 34 year old man was admitted to hospital on 30 March, 1988 because of abnormal liver tests over a year. He had a 10 year history of chronic pelvic

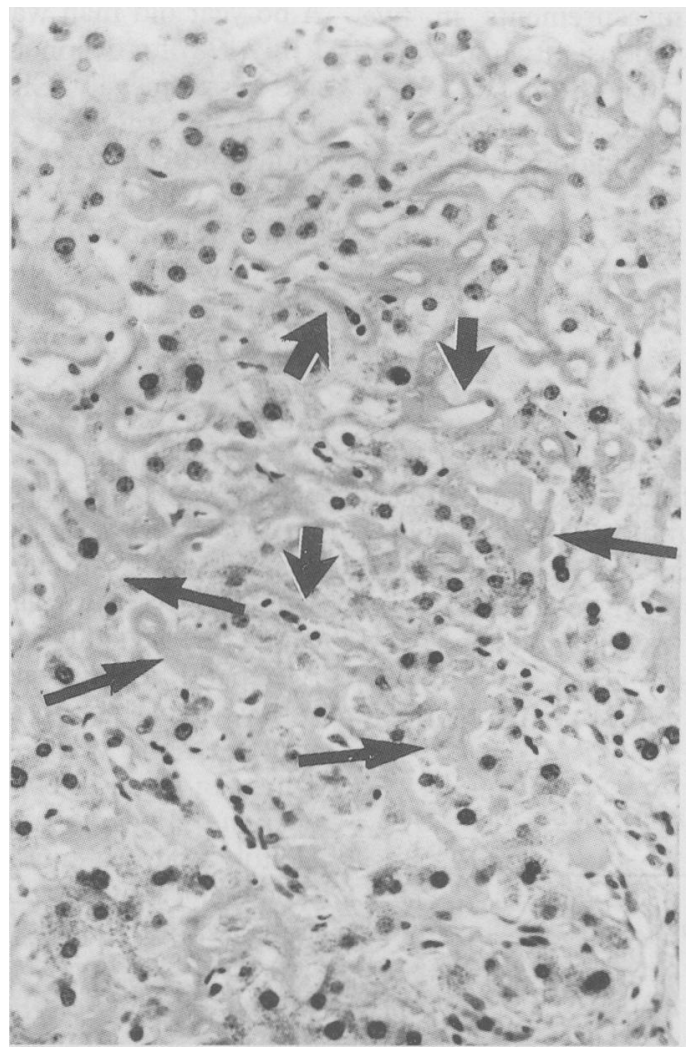

Figure 1: Patient 2: large and diffuse perisinusoidal amyloid deposits (thin arrows) with compression of hepatic sinusoids (large arrows). (Sirius red, original magnification $\times 400$.) suppuration of unknown origin. Clinical examination showed a slight hepatomegaly measuring $12 \mathrm{~cm}$ on the right mid-clavicular line; ascites was not detected on abdominal ultrasound. Results of liver tests are given in Table I. A moderate renal failure (creatinine: $146 \mu \mathrm{mol} / \mathrm{l}$ ) had been found two years earlier. Hepatic venous catheterisation showed wedged and free hepatic venous pressures of 11 and $10 \mathrm{mmHg}$ respectively, and a pressure gradient of $1 \mathrm{mmHg}$. Right atrial pressure was $8 \mathrm{mmHg}$. Histological examination of a transvenous liver biopsy specimen showed thin amyloid deposits in the Disse's space (Fig 2). One year later, he was in good condition.

\section{PATIENT 5}

A 70 year old man was admitted to hospital on 11 December 1978 for fatigue and anorexia that had lasted six months. Clinical examination showed a firm hepatomegaly measuring $15 \mathrm{~cm}$ on the right mid-clavicular line; ascites and splenomegaly were absent. There was no skeletal manifestation. Results of liver tests are given in Table I. An $M$ component (IgG kappa) was present in the serum and kappa light chains in urine. A severe renal failure (creatinine: $1050 \mu \mathrm{mol} / \mathrm{l}$ ) was present with proteinuria of $2 \cdot 5$ to $7 \mathrm{~g} /$ day. Endoscopy showed no oesophageal varices. Hepatic venous catheterisation showed wedged and free hepatic venous pressures of 10 and $7 \mathrm{mmHg}$ respectively, and a pressure gradient of $3 \mathrm{mmHg}$. Right atrial pressure was $2 \mathrm{mmHg}$. Histological examination of transvenous liver biopsy specimen showed discrete perisinusoidal amyloid deposits. Submucosal deposits of

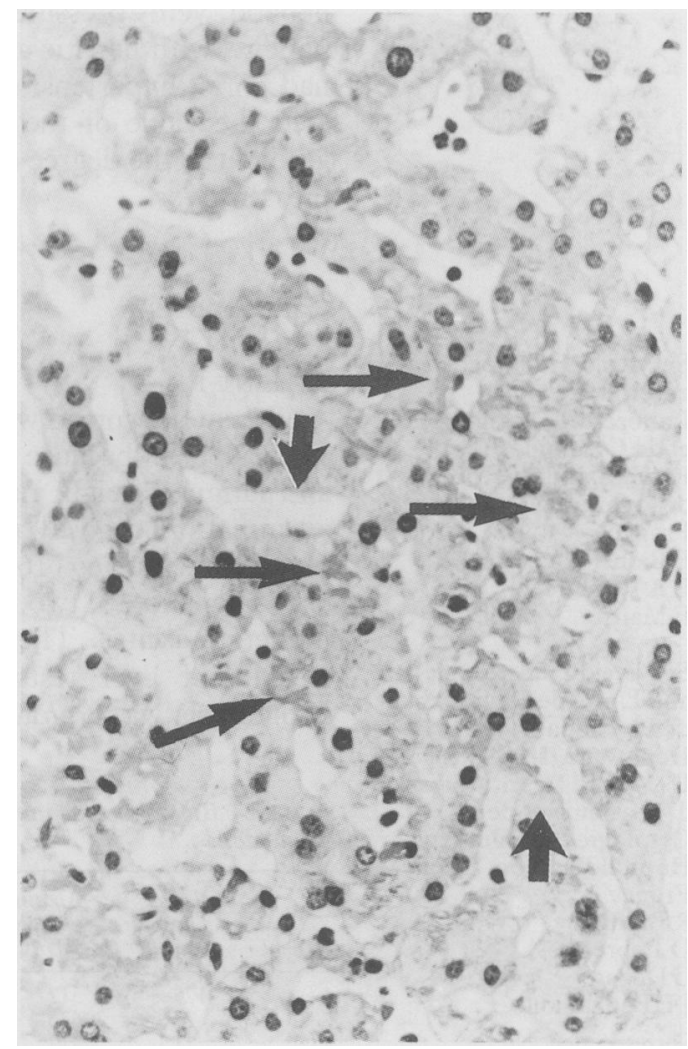

Figure 2: Patient-4: discrete and sparse amyloid deposits in the Disse's space (thin arrows) with normal lumen of hepatic sinusoids (large arrows). (Sirius red, original magnification $\times 400$.) 
TABLE II Clinical features of 14 patients with hepatic amyloidosis and portal hypertension

\begin{tabular}{|c|c|c|c|c|c|c|}
\hline Authors & $\begin{array}{l}\text { Sex/ } \\
\text { age } \\
\text { (yr) }\end{array}$ & Ascites & $\begin{array}{l}\text { Oesophageal } \\
\text { varices }\end{array}$ & $\begin{array}{l}\text { Gastrointestinal } \\
\text { bleeding }\end{array}$ & $\begin{array}{l}\text { Delay between } \\
\text { diagnosis and } \\
\text { death (mths) }\end{array}$ & Cause of death \\
\hline Melkebeke $e t a l^{s}$ & $F / 71$ & - & + & + & 5 & $\begin{array}{l}\text { Haemorrhage and } \\
\text { renal failure }\end{array}$ \\
\hline Atkinson $^{6}$ & M/46 & + & + & + & 12 & General inanition \\
\hline Pocock et al & $\mathrm{M} / 57$ & - & + & + & 8 & Haemorrhage \\
\hline Czyzyk et $a l^{8}$ & $\mathrm{~F} / 43$ & + & + & + & 18 & Haemorrhage \\
\hline Burgi $^{9}$ & $\mathrm{M} / 51$ & + & + & + & 3 & Hepatic failure \\
\hline $\mathrm{Kapp}^{10}$ & M/46 & - & + & + & 36 & $\begin{array}{l}\text { Haemorrhage and } \\
\text { renal failure }\end{array}$ \\
\hline Brandt et al" & ns & ns & + & + & ns & Haemorrhage \\
\hline Singh et al ${ }^{12}$ & $\mathrm{M} / 47$ & + & - & + & 1 & Haemorrhage \\
\hline Itescu $^{13}$ & $\mathrm{~F} / 72$ & + & - & - & $0 \cdot 3$ & Renal failure \\
\hline Prieto et $\mathrm{l}^{14}$ & $M / 46$ & + & + & + & $0 \cdot 2$ & $\begin{array}{l}\text { Haemorrhage and } \\
\text { renal failure }\end{array}$ \\
\hline $\begin{array}{l}\text { Case report, } \\
\quad N E n g l \mathcal{F} \mathrm{Med}^{\prime s}\end{array}$ & ${ }_{15} \mathrm{~F} / 43$ & + & + & + & 6 & $\begin{array}{l}\text { Haemorrhage and } \\
\text { renal failure }\end{array}$ \\
\hline Ayadi et $a l^{16}$ & M/61 & + & + & - & 2 & ns \\
\hline Our patient 1 & $\mathrm{~F} / 62$ & + & - & + & 0.5 & Renal failure \\
\hline Our patient 2 & $M / 66$ & + & - & - & 5 & Renal failure \\
\hline
\end{tabular}

$+=$ present; $-=$ absent; $\mathbf{n s}=$ not specified. ${ }^{\star}$ From ruptured oesophageal varices or other causes.

amyloid were not found in gastric biopsy specimens. Bone marrow biopsy tissue showed infiltration with mature plasmocytes and interstitial deposits of amyloid. Primary AL type amyloidosis with severe renal involvement was diagnosed. The patient received supportive treatment only and died from terminal renal failure one year after admission.

\section{Discussion}

The liver is affected in approximately $60 \%$ of patients with amyloidosis. ${ }^{1-5}$ Portal hypertension, however, seems to be an uncommon complication of this disorder. It has previously been reported in only 12 patients with hepatic amyloidosis (Table II). ${ }^{5-16}$ We report two patients with portal hypertension complicating hepatic amyloidosis. In five reported patients, portal hypertension was present without clinical manifestations. In two patients, oesophageal varices were present at necropsy, ${ }^{68}$ and in two at endoscopy. ${ }^{516}$ In one patient, increased portal pressure was measured at laparotomy..$^{13}$ In seven reported patients and in two of our patients, gastrointestinal bleeding due to ruptured oesophageal varices, ${ }^{7-11}$ ascites with splenomegaly, ${ }^{14}$ or prominent abdominal veins ${ }^{12}$ led to the diagnosis of portal hypertension. In our two patients, portal hypertension was shown by hepatic vein catheterisation performed for transvenous liver biopsy - transparietal liver biopsy being contraindicated in those patients with massive hepatic amyloidosis. ${ }^{1718}$ The absence of oesophageal varices in our two patients and in two reported patients $^{1213}$ with hepatic amyloidosis complicated by portal hypertension, may be explained by a mild increase in portal pressure which does not allow collateral circulation to develop. A rapid deterioration in the patient's condition may also contribute to the absence of the development of oesophageal varices.

The prevalence of ascites is high in amyloidosis, ranging from 15 to $47 \% .^{1219}$ In patients with hepatic amyloidosis, ascites may be the result of multiple causes, the commonest being hypoalbuminaemia due to the nephrotic syndrome and cardiac failure. The role of portal hypertension, however, was suggested by Levine, who found ascites in $21 \%$ of patients with and in only
$8 \%$ of those without hepatic amyloidosis. ${ }^{1}$ Hypoalbuminaemia in our patient 1 and cardiac failure in patient 2 were probably associated factors for ascites formation.

Portal hypertension in patients with hepatic amyloidosis is of the sinusoidal type since the gradient between wedged and free hepatic venous pressures in our patients 1 and 2 was high (12 and $16 \mathrm{mmHg}$ respectively). Portal hypertension was related to the degree of hepatic infiltration. Sinusoidal portal hypertension is ascribed to the reduction in the vascular space of hepatic sinusoids by abundant and diffuse amyloid deposits in the Disse's space and a subsequent reduction in the sinusoidal lumen (Fig 1). Experimental observations have suggested that decreased intrahepatic vascular space caused by hepatic resection leads to portal hypertension. ${ }^{20}$ Massive amyloid deposits in the Disse's space were found in our two patients with portal hypertension and hepatic amyloidosis as well as in other previously reported patients. ${ }^{5-9} 9^{13-16}$ Centrilobular vein lesions, periportal fibrosis, or regenerating nodules were absent in all these patients. In our three patients without portal hypertension, the amyloid deposits, although also present in the Disse's space, were, however, discrete and sparse (Fig 2). Deposition of amyloid predominates in the Disses's space in primary amyloidosis but is limited to walls of blood vessels in secondary amyloidosis. ${ }^{321}$ The morphological differences in the pattern of liver amyloid infiltration in primary and secondary amyloidosis may explain why portal hypertension developed mostly in patients with primary amyloidosis. ${ }^{5-12}$

Portal hypertension in patients with hepatic amyloidosis carries a poor prognosis - of nine patients suffering from gastrointestinal bleeding $^{5-111415}$ related to ruptured oesophageal varices, seven died. ${ }^{57810111415}$ Death occurred between six days and 36 months after the recognition of hepatic involvement. Massive hepatic amyloidosis rarely leads to fatal hepatic failure.' In patients with amyloidosis, other factors can lead to gastrointestinal bleeding, including acquired clotting factor deficiencies, ${ }^{17}$ increased vessel permeability, ${ }^{8}$ and ulceration of the gastrointestinal tract due to amyloid infiltration. ${ }^{1017}$

In conclusion, portal hypertension is an uncommon complication of hepatic amyloidosis and is associated with a poor prognosis. In hepatic amyloidosis, portal hypertension is of the sinusoidal type and is related to the reduction of vascular space of hepatic sinusoids by massive perisinusoidal amyloid deposits.

1 Levine RA. Amyloid disease of the liver. Correlation of clinical, functional and morphologic features in forty-seven patients. Am $\mathcal{F}$ Med 1962; 33: 349-57.

2 Levy $M$, Polliack A, Lender $M$, Eliakim $M$. The liver in amyloidosis. Digestion 1974; 10: 40-51.

3 Chopra S, Rubinow A, Koff RS, Cohen AS. Hepatic amyloidosis: a histopathologic analysis of primary $(A L)$ and amyloidosis: a histopathologic analysis of primary (AL

4 Gertz MA, Kyle RA. Hepatic amyloidosis (Primary AL immunoglobulin light chain): the natural history in 80
patients. Am $\mathcal{F}$ Med 1988; 85: 73-80. patients. Am f Med 1988; 85: 73-80.

Melkebeke P, Vandepitte J, Hannon R, Fevery J. Huge hepatomegaly, jaundice and portal hypertension due to amyloidosis of the liver. Digestion 1980; 20: 351-7. 6 Atkinson AJ. Clinical-pathological conference. Gastro-
enterology 1946; 7: 477-82. 
7 Pocock DS, Dickens J. Paramyloidosis with diabetes mellitus and gastrointestinal hemorrhage. N Engl f Med 1953; 248: 8 Czyzyk A, Caroli J. Amylose hépatique primaire. I. Etude
clinique avec présentation de 6 cas. Rev Int Hepatol 1961; 11: 589-640.

9 Burgi W. Primäre und sekundäre leberamyloidose. Dtsch Arch Klin Med 1962; 207: 585-601.

$10 \mathrm{Kapp} \mathrm{J}$. Hepatic amyloidosis with portal hypertension. fAMA 1965; 191: 497-9.

11 Brandt K, Cathcart ES, Cohen AS. A clinical analysis of the course and prognosis of forty-two patients with amyloidosis. Am F Med 1968; 44: 955-69.

12 Singh SV, Goyal SK, Khabiya BL. Primary amyloidosis with portal hypertension and erythrocytosis. $\mathcal{F}$ Assoc Physicians

13 Itescu S. Hepatic amyloidosis. An unusual cause of ascites and portal hypertension. Arch Intern Med 1984; 144: 2257-9.

14 Prieto JM, Monreal FA, Canedo FV, Pedreira JD. Amiloidosis hepatica e hipertension portal. Med Clin (Barc) 1986; 87 869-70.
15 Case records of the Massachusetts General Hospital (50-1987). N Engl F Med 1987; 314: 1520-31.

16 Ayadi S, Jaafoura H, Dellagi K, Ben Amor N, Louzir B, Gargouri M. Amylose hépatique. A propos de deux observations. Med Chir Dig 1988; 17: 349-51.

17 Cohen AS, Skinner M. Amyloidosis of the liver. In: Schiff L Schiff ER, eds. Diseases of the liver. 6th edition. Philadelphia: J B Lippincott, 1988: 1093-108.

18 Stauffer MH, Gross JB, Foulk WT, Dahlin DC. Amyloidosis: diagnosis with needle biopsy of the liver in eighteen patients. Gastroenterology 1961; 41:92-6.

19 Gregg JA, Herskovic T, Bartholomew LG. Ascites in systemic amyloidosis. Arch Intern Med 1965; 116: 605-10.

20 Lee SS, Hadengue A, Girod C, Braillon A, Lebrec D. Reduction of intrahepatic vascular space in the pathogenesis of portal hypertension. In vitro and in vivo studies in the rat. Gastroenterology 1987; 93: 157-61.

21 Looi LM, Sumithran E. Morphologic differences in the pattern of liver infiltration between systemic $A L$ and $A A$ amyloidosis. Hum Pathol 1988; 19: 732-5. 